«Системні технології» 4 (129) 2020 «System technologies»

DOI 10.34185/1562-9945-4-129-2020-03

УДК 629.78.533.6.013:621.45

Н.П. Сироткина, А.О. Кириченко

\title{
РАСШИРЕНИЕ ФУНКЦИОНАЛЬНЫХ ВОЗМОЖНОСТЕЙ РЕГУЛИРУЕМОГО ЖИДКОСТНОГО РАКЕТНОГО ДВИГАТЕЛЯ
}

Аннотация. Предложено решение, которое может использоваться в перспективных проектах при создании быстроманевренных жидкостных ракет, для управления которыми необходимо управление и модулем, и направлением, а также необходимо создавать момент вращения вокруг оси ракеты (момент крена). Обычно это решается путем применения отдельных органов управления: по модулю, направлению и крену.

Обосновано новое решение по расширению функциональных возможностей регулируемого жидкостного ракетного двигателя, а именно, дополнительное управление направлением вектора тяги и создание вращательного момента вокруг оси двигателя. Это достигается установкой центрального тела на шарнирном узле и твердого препятствия в области критического сечения сопла с инжекцией через него жидкости в поток камерного газа, набегающего на препятствие.

Показано, что данное решение позволяет объединить в одном двигателе все функции управления вектором тяги, что упрощает систему управления вектором тяги быстроманевренной ракеты, повышает ее энергомассовые характеристики и надежность системы управления полетом в целом.

Ключевые слова: ракетный двигатель, регулирование вектора тяги, чентральное тело тарельчатого типа, шарнир, интерцептор.

Введение. Для управления быстроманевренными жидкостными ракетами необходимо управление и модулем и направлением, а также необходимо создавать момент вращения вокруг оси ракеты - так называемый момент крена. Обычно это решается путем применения отдельных органов управления: по модулю, направлению и крену. Большими возможностями по обеспечению регулирования модуля и направления вектора тяги ракетного двигателя обладают кольцевые сопла с внутренним расширением газового потока. Исследования механизмов управления направлением вектора тяги ракетного двигателя показали преиму-

(C) Сироткина Н.П., Киричен А.О., 2020 
«Системні технології» 4 (129) 2020 «System technologies»

щества газодинамического способа управления (возмущением сверхзвукового потока препятствием на обтекаемой стенке сопла) для кольцевых сопел.

Постановка проблемы. Газодинамические процессы, протекающие в тарельчатом сопле, при возмущении сверхзвукового потока инжектируемыми струями или твердыми интерцепторами на обечайке сопла, имеют существенные особенности в сравнении с процессами в сопле Лаваля. Это обусловлено тем, что в истекающем из тарельчатого сопла газовом потоке имеется донная область за центральным телом, формирующая «газовую стенку» кольцевой струи за центральным телом. Это может приводить к проникновению в донную область и на противоположную стенку сопла возмущений сверхзвукового потока, что влияет на осевую тягу сопла.

Анализ последних исследований и публикаций. В результате исследований были рассмотрены регулируемые двигатели, базирующиеся на сопле с перемещением в осевом направлении ЦТ, с регулированным модулем и направлением ВТ. Существуют различные способы и устройства управления вектором тяги (BT) жидкостных ракетных двигателей: как механические (в частности, качанием сопла) так и газодинамические (в частности, возмущением сверхзвукового потока в сопле) [1-5]. Для управления высокоманевренными ракетами необходимо регулирование величины тяги (продольным перемещением ЦТ), управление направлением, а также необходимо создавать момент вращения вокруг оси ракеты (момент крена) [6-7]. Исследования механизмов управления направлением вектора тяги ракетного двигателя показали преимущества газодинамического способа управления (возмущением сверхзвукового потока препятствием на обтекаемой стенке сопла) для кольцевых сопел [7]. Обеспечение высоких характеристик ракет и расширение их функциональных возможностей является важнейшими задачами дальнейшего усовершенствования ракетно-космической техники.

Цель работы заключается в обосновании нового решения по расширению функциональных возможностей регулируемого жидкостного ракетного двигателя, а именно, дополнительного управления направ- 
«Системні технології» 4 (129) 2020 «System technologies»

лением вектора тяги и созданием вращательного момента вокруг оси двигателя.

Основная часть. Для расширения функциональных возможностей ракетного двигателя предлагается создавать управляющие усилия на поверхностях, обтекаемых потоком в сопле. Это достигается установкой центрального тела на шарнирном узле и твердого препятствия в области критического сечения сопла с инжекцией через него жидкости в поток камерного газа, набегающего на препятствие. При этом выделяются отдельные процессы и подсистемы управления ВТ с последующим их объединением. Возмущения потока в сопле ракетного двигателя препятствиями различной природы позволяют обеспечить управление вектором тяги двигателя во всех плоскостях стабилизации ракеты. Для ракетного двигателя с тарельчатым соплом это достигается установкой центрального тела на шарнирном узле и твердого препятствия (интерцептора) с инжекцией через него жидкости в области критического сечения сопла.

Продольное перемещение ЦТ камеры осуществляется путем перемещения подвижного днища форсуночной головки, соединенного с ЦТ, а расход топлива регулируется с помощью регулируемых форсунок, жестко соединенных с подвижным днищем форсуночной головки. Для создания боковой управляющей силы ЦТ перемещается в поперечном направлении с помощью силы, создаваемой выдвинутыми (по командам от системы управления ракетой) в поток газа в критическом сечении сопла твердыми препятствиями (интерцепторами), установленными в плоскостях стабилизации (тангаж и рыскание) ракеты и возмущающими поток газа.

Крутящий момент относительно оси двигателя (креновый момент ракеты) создается узлами впрыска компонента топлива, находящимися в твердом препятствии (интерцепторе). Оси отверстий впрыска ориентированы в тангенциальном направлении относительно периметра сечения сопла, в котором установлены твердые препятствия. При этом направления выхода отверстий в диаметрально противоположных препятствиях (интерцепторах) противоположны друг другу. Таким образом, 20 


\section{«Системні технології» 4 (129) 2020 «System technologies»}

впрыскивание жидкости через эти отверстия создает крутящий момент относительно оси двигателя, который имеет разный знак для взаимно перпендикулярных плоскостей, в которых установлены твердые препятствия (интерцепторы).

Предложенный регулируемый жидкостной ракетный двигатель представлен на рис. 1.
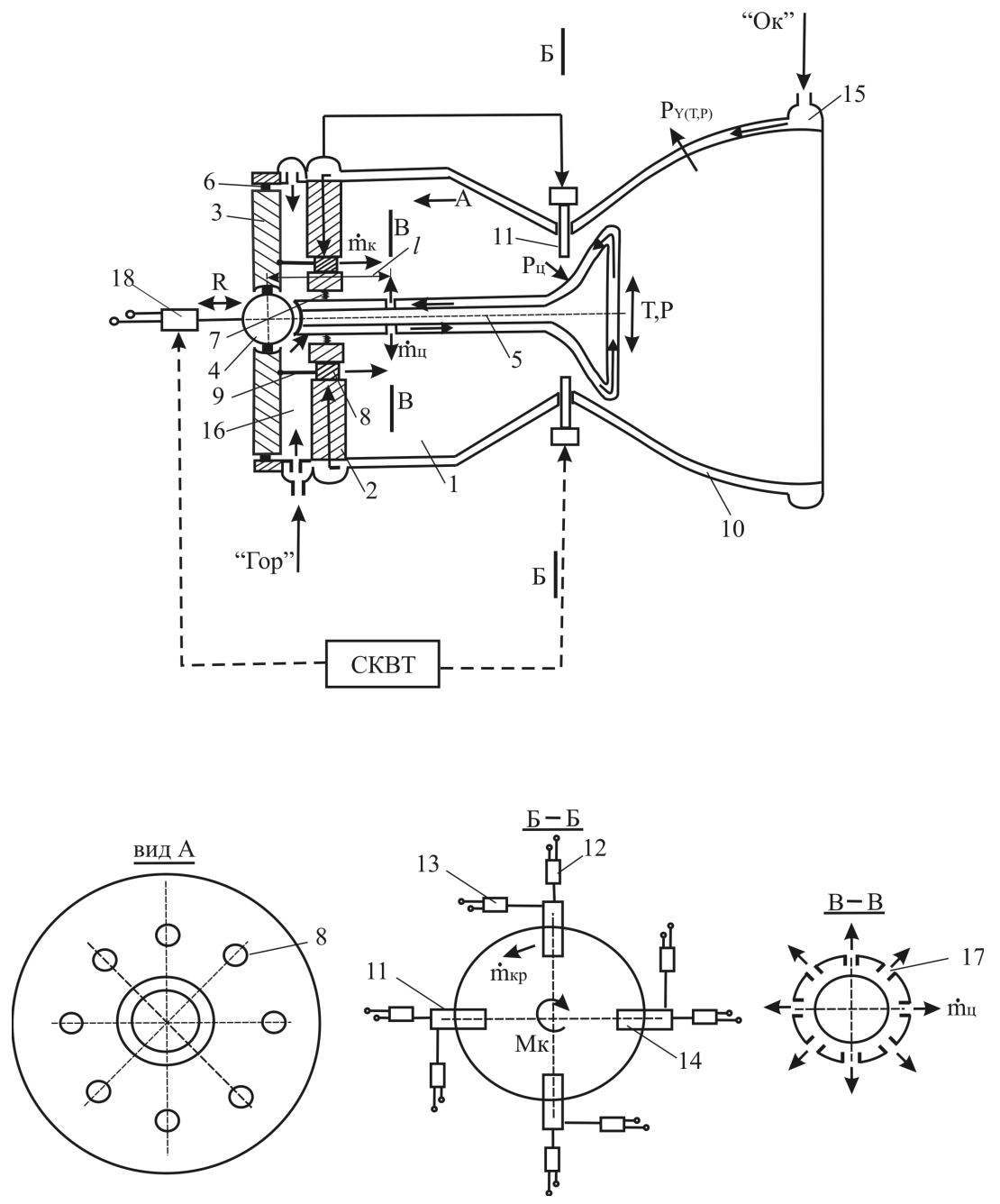

Рисунок 1 - Регулируемый жидкостной ракетный двигатель

Камера сгорания 1 содержит форсуночную головку, которая включает неподвижное 2 и подвижное 3 днища. В подвижном днище 3 на шарнире 4 установлено ЦТ 5 тарельчатого типа. Подвижное днище 3 уплотняется относительно корпуса камеры кольцами 6. ЦТ 5 уплотняется относительно неподвижного днища 2 уплотнением 7, что позволяет ЦТ 5 
«Системні технології» 4 (129) 2020 «System technologies»

свободно перемещаться относительно днища как в продольном, так и в поперечном направлениях. В неподвижном днище 2 установлены форсунки 8 (вид А), регулируемые с помощью штоков 9, соединенных с подвижным днищем 3. В трансзвуковой области сопла 10 перед тарелью ЦТ установлены интерцепторы 11 (сечение Б - Б), которые могут выдвигаться в середину сопла на заданную высоту приводами 12 . В интерцепторы

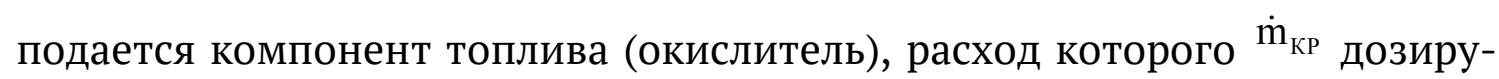
ется приводом 13 (сечение Б - Б). В интерцепторах выполнены отверстия 14 в поперечном сечении сопла для создания крутящего момента (момента крена) $\mathrm{M}_{\text {к }}$ К Камера сгорания охлаждается компонентом топлива (окислителем), который подается в коллектор 15. После охлаждения камеры компонент (окислитель) поступает к регулируемым форсункам 8, обеспечивая процесс горения. ЦТ охлаждается компонентом (горючее), отбираемым из полости 16 форсуночной головки. После охлаждения ЦТ компонент впрыскивается в камеру сгорания (сечение В - B) на расстоянии $l$ от шарнира, что обеспечивает свободное вытекание с расходом $\dot{\mathrm{m}}_{ц}$ через форсунки впрыска 17. Величина тяги $\mathrm{R}$ регулируется путем перемещения ЦТ в продольном направлении по командам от системы управления вектором тяги (СКВТ) при помощи привода 18. При этом изменяется площадь (зазор между тарелью и обечайкой сопла) критического се-

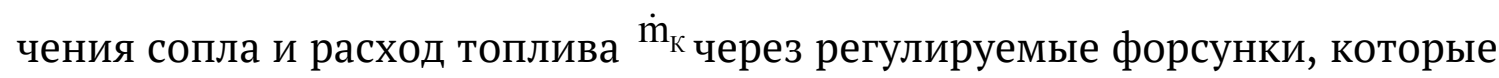
перемещаются штоками в осевом направлении вместе с подвижным днищем форсуночной головки.

Таким образом, в камере сгорания поддерживается постоянное давление процесса горения топлива при любых значениях тяги $R$. Направление вектора тяги (обусловленное силами $\mathrm{P}_{\mathrm{Y(T,P)}}$ в каналах тангаж и рыскание) осуществляется путем выдвижения в сопло на соответствующую высоту интерцепторов. При выдвижении интерцептора в сопло возникающая газодинамическая поперечная сила $\mathrm{P}_{ц}$ отодвигает ЦТ относительно шарнира в поперечном направлении. При этом возникает поперечная газодинамическая сила $\mathrm{P}_{\mathrm{Y(T,P)}}$ в соответствующей площади стаби22 
«Системні технології» 4 (129) 2020 «System technologies»

лизации $\left(\mathrm{P}_{\mathrm{Y}(\mathrm{T})}-\right.$ в плоскости тангажа, $\mathrm{P}_{\mathrm{Y(P)}}$ - в плоскости рыскания), которая обусловлена командами СКВТ. Момент крена $\left({ }^{\mathrm{M}_{\mathrm{K}}}\right)$ относительно оси камеры сгорания создается впрыскиванием через отверстия компонента топлива в диаметрально противоположные интерцепторы. При этом каждая пара диаметрально противоположных интерцепторов создает момент крена противоположного знака. Расход $\left(\dot{\mathrm{m}}_{\mathrm{kp}}\right)$ через отверстия интерцептора регулируется дозатором, который перемещается приводом по командам СКВТ.

Выводы. Показано, что установкой центрального тела на шарнирном узле и твердого препятствия в области критического сечения сопла с инжекцией через него жидкости в поток камерного газа, набегающего на препятствие решается задача объединения в одном двигателе всех функций управления вектором тяги. Это упрощает систему управления вектором тяги быстроманевренной ракеты, повышает ее энергомассовые характеристики и надежность системы управления полетом в целом.

\section{ЛИТЕРАТУРА / ЛІТЕРАТУРА}

1. Динамическое проектирование ракет. Задачи динамики ракет и их космических ступеней: моногр. / И. М. Игдалов, Л. Д. Кучма, Н. В. Поляков, Ю. Д. Шептун; под ред. С. Н. Конюхова. - Днепропетровск: изд-во Днепропетр. нац. ун-та, 2010. - 254 с.

2. Патент на винахід 2681733 Россия, МПК F02К 9/62. Камера ЖРД / Космачева В. П., Кафарена П. В., Хрисанфов С.П.; заявник і патентоволодар АО «Конструкторское бюро химавтоматики». - 2017146960; заявл. 28.12.2017, опубл. 12.03.2019, Бюл. № 8. - 7 с.

3. Патент на винахід 20181590 NO, MПК F02K 9/80. Valve for a controllable transverse thrust engine / John Livingston, Charlese Lipsey; заявник і патентоволодар Ajinomoto co., Internetional trade cjmmission. - Filed: заявл. 12.12.2018; опубл.17.06.2019, Appl. No. 84544. - 9 с.

4. Патент на винахід 0002532445 Россия, МПК F02K 9/00. Компоновка многоступенчатой ракеты-носителя / Юрьев В. Ю., Чванов В. К., Стернин Л. Е., Ширшов В.Е., Денисов А. Э.; заявник і патентоволодар ОАО «НПО Энергомаш имени академика В. П. Глушко», ФГУП «ГКНП центр 
«Системні технології» 4 (129) 2020 «System technologies»

им. В. М. Хруничева». - 2013110851/11; заявл. 20.11.2012; опубл. 10.14.2014, Бюл. № 9. - 9 с.

5. Патент на винахід 2610873 Россия, МПК F02K 9/00. Компоновка маршевой многокамерной двигательной установки двухступенчатой ракетыносителя с составным сопловым блоком / Денисов А. Э., Крайко А. Н., Стернин Л. Е., Ширшов В. Е. и др.; заявник і патентоволодар ОАО «НПО Энергомаш имени академика В. П. Глушко» и др. - 2015131047; заявл. 27.07.2015; опубл. 17.02.2017, Бюл. № 5. - 8 с.

6. Патент на винахід 2143921 Франция, МПК F02K 9/00. Liquid-propellant rocket engine with propulsion chamber blanking plug / Thevenet Jean-Bruno, Cabinet Breau de lomenle. - 091649863; заявл. 09.07.2009; опубл. 29.02.2012, Бюл. № 9. - 10 с.

7. Pryadko N. S. The increasing efficiency of combined thust vector control of rocket engine / N. S. Pryadko, N. P. Syrotkina, E. L. Tokareva // Техническая механика. - 2019. - № 2. - С. 30 - 38.

\section{REFERENCES}

1. Dynamic rocket design. Problems of the dynamics of rockets and their space stages: monograph. / I. M. Igdalov, L. D. Kuchma, N. V. Polyakov, Yu. D. Sheptun; under the editorship of S. N. Konyukhova. - Dnepropetrovsk: Publishing house Dnepro-petr. nat. University, 2010 . -254 p.

2. Patent for invention 2681733 Russia, Kosmacheva VP, Kafarena PV, Khrisanfov SP; LRE camera, applicant and patent holder of JSC Constructor Bureau of Chemistry. - 2017146960; claimed 12/28/2017, published 12/12/2019, Bul. № 8. - 7 p

3. Patent for invention 20181590 NO Valve for a controllable transverse thrust engine/John Livingston, Charlese Lipsey; publ.7.06.2019,No.84544.-9p. 4. Patent for invention 0002532445 Russia, Yuryev V.Yu., Chvanov VK, Sternin LE, Shirshov VE, Denisov AE; Applicant and patent holder of OAO NPO Energomash named after Academician VP Glushko, Federal State Unitary Enterprise “GKNP Center them. V. Khrunicheva-publ.10.14.2014, Bul.№9-9p. 5. Patent for invention 2610873, Russia Arrangement of a multi-chamber propulsion system of a two-stage launch vehicle with a composite nozzle unit / Denisov AE, Krajko AN, Sternin LE, Shirshov VE, etc .; applicant and patent holder of OAO NPG Energomash named after Academician VP Glushko, etc. 2015131047; claimed 27.07.2015; publ. 17/02/2017, Bul. № 5. - 8 p. 
«Системні технології» 4 (129) 2020 «System technologies»

6. Patent for invention 2143921 France, IPC F02K 9/00. Liquid-propellant rocket engine with propulsion chamber blanking plug / Thevenet Jean-Bruno, Cabinet Breau de lomenle. - 091649863; claimed 09.07.2009; publ. 02/29/2012, Bul. № 9. - 10 p.

7. Pryadko N.S. The increasing efficiency of combined thust vector control of rocket engine / N. S. Pryadko, N. P. Syrotkina, E. L. Tokareva // Tech. mech. 2019. - № 2. - P. 30 - 38.

\section{Розширення функціональних можливостей регульованого рідинного ракетного двигуна}

Received 18.02.2020. Accepted 21.02.2020.

Запропоноване рішення може бути використано в перспективних проектах при створенні швидкоманеврених рідинних ракет, для керування якими необхідно управління $i$ модулем і напрямком, а також необхідно створювати момент обертання навколо осі ракети (момент крену). Зазвичай че вирішується шляхом застосування окремих органів управління: по модулю, напрямку і крену.

Обгрунтовано нове рішення по розширенню функціональних можливостей регульованого рідинного ракетного двигуна, а саме, додаткового управління напрямком вектора тяги і створенням обертального моменту навколо осі двигуна. Це досягається установкою центрального тіла на шарнірному вузлі і твердої перешкоди в області критичного перетину сопла з інжекцією через нього рідини в потік камерного газу, що набігає на перешкоду.

Показано, що дане рішення дозволяє об'єднати в одному двигуні всі функції управління вектором тяги, що спрощує систему управління вектором тяги швидкоманевренної ракети, підвищує іï енергомасові характеристики $i$ надійність системи управління польотом в цілому.

\section{Expanding the functionality of an adjustable liquid rocket engine}

To reliably ensure the mission of the rocket flight, it is important to increase the accuracy, efficiency and reliability of the system to ensure the necessary navigational characteristics of rocket movement. Ensuring high rocket characteristics and expanding their functional capabilities are the most important tasks for the further improvement of rocket and space technology. The task of the thrust vector control of a rocket engine through all channels of rocket stabilization is achieved by using separate control bodies: in modulus, direction and roll.

The purpose of the work is to justify a new solution of expanding the functionality of an adjustable liquid propellant rocket engine, namely, additional control of the thrust vector direction and the creation of torque about the engine axis.

Main researches. In order to expand the functionality of a rocket engine, it is proposed to create control forces on flowing surfaces in the nozzle. This is achieved by installing a central body on the hinge assembly and a solid obstacle in the critical nozzle section with the injection of liquid through it into the flow of chamber gas running on the obstacle. At the same time, separate processes and subsystems of thrust vector control are distinguished with their subsequent integration. The flow perturbations in the rocket engine nozzle with obstacles of various natures make it possible to control the thrust vector of the engine in all planes of rocket stabili- 
«Системні технології» 4 (129) 2020 «System technologies»

zation. For a rocket engine with a disk nozzle, this is achieved by installing a central body on the hinge assembly and a solid obstacle (interceptor) with liquid injection through it in the region of the nozzle critical section.

It was found that additional control of the direction of the thrust vector and the creation of torque around the engine axis simplify the thrust vector control system of a fast maneuverable rocket; increase its energy-mass characteristics and the reliability of the flight control system as a whole. Research on the development of controlled liquid rocket engines has shown the advantages of using annular nozzles with axial movement of the central body. Annular nozzles with internal expansion of the gas stream have great potential for providing regulation of the module and the thrust vector direction of the rocket engine. The proposed solution can be used in promising projects for creation fast-maneuverable liquid rockets.

Сироткина Наталия Петровна - младший научный сотрудник Института технической механики НАНУ и ГКАУ.

Кириченко Александр Олегович - младший научный сотрудник Института технической механики НАНУ и ГКАУ.

Сироткіна Наталія Петрівна -молодший науковий співробітник Института технической механики НАН Украины и ГКА Украины.

Кириченко Олександр Олегович -молодший науковий співробітник Института технической механики НАН Украины и ГКА Украины.

Syrotkina Nataliya - Junior Researcher, Institute of Technical Mechanics of the National Academy of Sciences of Ukraine and State Space Agency of Ukraine.

Kirichenko Oleksander - Junior Researcher, Institute of Technical Mechanics of the National Academy of Sciences of Ukraine and State Space Agency of Ukraine. 